\title{
Barndomens placeringar och ungas tillbakablick
}

\author{
GUNVOR ANDERSSON
}

\begin{abstract}
En grupp små barn med tidiga erfarenheter av samhällsvård har följts upp med jämna mellanrum under hela barndomen. Den här artikeln handlar om deras placeringshistoria samt om hur de i slutet av barndomen och som unga vuxna ser tillbaka på sina erfarenheter.
\end{abstract}

\begin{abstract}
Utfallet av familjehems- och institutionsvård framstår som dystert i jämförelse med hur barn i allmänhet har det, som inte kommer i beröring med samhällsvård. Det framgår av många forskningsrapporter både i vårt land och i andra länder. Samtidigt efterlyses mer forskning, fler longitudinella studier och studier som tar med barns eget perspektiv. Denna artikel handlar om ett forskningsprojekt som följt en grupp barn från småbarnsåldern och in i vuxen ålder, alla med kortare eller längre erfarenhet av samhällsvård. Nu är projektet avslutat och den svåra frågan återstår: Hur ska jag kunna redovisa det rikhaltiga forskningsmaterialet på ett allsidigt och rättvisande sätt? Det ter sig närmast omöjligt, även om det bara handlar om 26 barn. Det finns inte bara en sanning eller en verklighet utan
\end{abstract}

Gunvor Andersson, leg.psykolog och professor i socialt arbete, Socialhögskolan, Lunds universitet flera möjliga. Svaret på frågan om hur det går för barn i samhällsvård blir olika beroende på om det är stabilitet/instabilitet i placeringar som avses eller välbefinnande/ hälsa eller relationer till familj/fosterfamilj eller social anpassning/skolgång/laglydighet. I vad mån utfallet kan relateras till samhällsvård är beroende av hur länge barnen varit placerade och vid vilken ålder de placerades, omplacerades, flyttade hem eller återplacerades. Svaret blir också olika om resultat avläses under pågående vård, vid vårdens avslutning eller i vuxen ålder. Det kan också bli olika resultat om svaren hämtas från journaler, sociala akter och register, från standardiserade frågeformulär och skattningsskalor eller från intervjuer med föräldrar, fosterföräldrar eller barn.

Den här artikeln avgränsas till två frågor. Den ena frågan är barnens placeringshistoria eller "vårdkarriär" (jfr. "career in the care system», Sinclair et al. 2006). Stabilitet/ 
instabilitet i placeringar utanför det egna hemmet är ett vanligt resultatmått i internationell forskning: "Placement is outcome» (Ward \& Jackson 1991 s. 398). I det forskningsprojekt, som denna artikel handlar om, finns en ovanligt heltäckande kunskap om barndomens (0-18 år) placeringar, sammanbrott i placeringar, omplaceringar, hemflyttningar och återplaceringar. Den andra frågan är barnens "subjektiva» bild av de placeringar eller flyttningar som de varit med om. Det finns mycket starka skäl att ge barns röst en mycket mer central plats och lyssna på deras levda erfarenhet (»lived experience», Gilligan 2000). I denna artikel är tonvikten på deras tillbakablick, när de har kommit längre i sitt liv och kan reflektera över barndomens placeringar/flyttningar utan att deras utsagor riskerar frånkännas värde på grund av att de är barn och beroende av de vuxna omkring sig (jfr. Egelund Nielsen 2001).

Undersökningsgruppen representerar ett homogent urval av barn, som tidigt i livet placerades utanför hemmet på grund av en stor ansamling av sociala problem i familjen. I den fortsatta "vårdkarriären" finns ändå variation, liksom det finns variation i deras syn på barndomens placeringar eller flyttningar. Före presentation av metod och resultat ges en inblick i annan forskning om stabilitet/instabilitet i placeringar och barns perspektiv.

\section{Forskningsområdet}

\section{Stabilitet/instabilitet $i$ placeringar}

Många studier har använt sammanbrott eller oplanerade avbrott (breakdown, disruption) i vården som ett mått på misslyckande (se Sinclair et al. 2006). Tine Egelunds (2006) översikt ger en god inblick i internationell forskning om sammanbrott i placeringar. Den visar t.ex. att studier om sammanbrottsfrekvensen vanligen bygger på uppföljning av placeringar under en begränsad tidsperiod och att sammanbrott är ett särskilt bekymmer i tonårsplaceringar.

En svensk aktstudie om sammanbrott i tonårsplaceringar (Sallnäs et al. 2004, Vinnerljung et al. 2001) omfattar 766 tonåringar i 13-16-årsåldern, som påbörjade en placering i dygnsvård 1991, vilket betyder cirka 70 procent av alla i sin åldersgrupp som placerades i vårt land det året. Deras placeringshistoria har följts under den tid de var placerade, som längst fram till 18-årsdagen. Räknat på alla placeringsformer var 63 procent av tonåringarna inte med om något sammanbrott i sin placering medan 30 procent av dem var med om ett tydligt sammanbrott och för ytterligare sju procent var det ett otydligt eller misstänkt sammanbrott. Vanligast var sammanbrott $i$ enskilda HVB (Hem för vård eller Boende) och därnäst i familjehem. När familjehem delas upp i olika typer visar sig sammanbrottsfrekvensen något högre i »vanliga familjehem», som inte kände barnet sedan tidigare, än i "nätverkshem», som kände barnet utan att vara släkt. Ytterligare något lägre var den i familjehem, som tidigare varit barnets kontaktfamilj, och lägst var den i släktinghem.

Det är inte bara oplanerade avbrott eller sammanbrott i samhällsvård som avgör frågan om stabilitet eller instabilitet i vården. Återplacering i samhällsvård efter 
en tid hemma är också en form av instabilitet. I en registerundersökning med syfte att studera återplaceringar konstaterar forskarna Vinnerljung et al. (2004a) att de knappast har några andra studier att jämföra med, eftersom de studier som gjorts i USA inte är jämförbara. Undersökningsenheten i deras studie var avslutade vårdperioder (1989-1998) för barn 0-15 år. För varje avslutad vårdperiod har barnen följts i två år framåt för att undersöka förekomst av återplacering. Det visade sig att av de barn som var under tio år, när vården avslutades, återkom cirka en fjärdedel i vård inom två år. Av 10-12-åringarna återkom 30 procent och av 13-15-åringarna återkom 40 procent inom två år. De som varit i vård i mer än två år återplacerades i mindre utsträckning. Vilka föräldrarelaterade faktorer som ökar eller minskar risken för återplacering av återförenade barn är en fråga som besvaras i en annan artikel med hjälp av ytterligare register (Vinnerljung et al. 2004b). Ansamlingen av riskindikatorer på individuell nivå visade sig ha avgörande betydelse, men om riskindikatorerna låg på föräldrarna eller barnen var beroende av barnens ålder.

I en metaanalys av 26 studier om sammanbrott ("disruption») i familjehemsvård (Oosterman et al. 2007) framkom att många olika faktorer kan bidra till ökad risk för sammanbrott och att ingen enskild faktor är avgörande. Ålder var mer utslagsgivande än andra faktorer men en faktor som modererades av kön, eftersom äldre flickor hade fler erfarenheter av sammanbrott än både yngre flickor och pojkar. Släktingplaceringar gav inte det skydd mot sammanbrott, som framkommit i tidigare studier, konstaterar författarna bland annat.
De brittiska forskarna Ian Sinclair et al. (2006) menar, som en slutsats av sin fosterbarnsstudie, att synen på samhällsvård ("parenting by the state») som dyrt och ineffektivt och något som bara ska tas till som en sista möjlighet och så temporärt som möjligt bidrar till hög grad av instabilitet i vården.

\section{Barns perspektiv}

Under de senaste decennierna har det blivit vanligt att i politik, social praktik och forskning eftersträva ett barnperspektiv eller efterlysa barns perspektiv. Det kan vara klargörande att skilja mellan barnperspektiv och barns perspektiv (se t.ex. Andersson \& Rasmusson 2006, Halldén 2003, Rasmusson 1994). Begreppet barnperspektiv omfattar då den samlade kunskapen om barn, som vuxna kan använda sig av när de vill försöka tänka och handla utifrån ett barnperspektiv. Det inkluderar att ta hänsyn till sammanhanget och vara medveten om att barnperspektivet är kopplat till tidpunkt i historien och plats i världen. Begreppet barns perspektiv reserveras då lämpligen för barns eget perspektiv, dvs. det som barn ser, hör, upplever och känner, det är det som är deras verklighet (Tiller 1991). I början av 1990-talet började forskare alltmer betona vikten av att se barn som aktiva subjekt och medskapare av sina egna sociala liv och inte som passiva objekt för sociala strukturer och processer. Det blir då viktigt att förstå barns sociala realitet genom att ta reda på dess innebörd för dem själva, i det sammanhang där det äger rum (se t.ex. Corsaro 2005, James et al. 1998). Forskare visade på nya sätt att forska om barn, se barn som sak- 
kunniga informanter och göra barn till medforskare istället för undersökningsobjekt (Andenæs 1991, Kampmann 1998).

Brukarperspektiv värdesätts i socialtjänstens kunskapsutveckling men anses inte tillämpligt på barn (Socialstyrelsen 2003). Brukarbegreppet i svensk social barnavård liksom i det norska "barnevernet» (Seim \& Slettebø 2007) är oklart, därför att det vanligen inkluderar både barn och föräldrar och ibland bara föräldrar. Barns perspektiv är ett begrepp med tydligare syfte. När Tine Egelunds och Anne-Dorte Hestbæk (2003) genomförde sin omfattande forskningsöversikt över forskning om omhändertagande av barn, fann de få studier som byggde på barns och ungas egna berättelser. De konstaterar att dessa studier ger en dyster bild av barns subjektstatus i manbringelsessager", detta i motsats till den bild av barn som självständiga medborgare med egna rättigheter, som lyfts fram $i$ andra sammanhang.

Det finns en del svenska studier som visar att barn (0-18 år) inte känner sig tillräckligt involverade i utredningar eller lyssnade på i uppföljning av insatser (Andersson \& Frick 1999, Cederborg \& Karlsson 2001, Claezon 2004). Bodil Rasmusson (2006, se även Rasmusson et al. 2004) har i både forsknings- och utvecklingsarbete arbetat med begreppen barns perspektiv och barns delaktighet i socialt arbete. En grundförutsättning för delaktighet är att vuxna lyssnar till barn, att barn får stöd i att uttrycka sina åsikter och att hänsyn tas till barns åsikter, vilket också är miniminivåer av delaktighet enligt FN:s barnkonvention. Det är en rättighet för barn att få uttrycka sin syn, att vuxna lyssnar och tar hänsyn till deras synpunkter (jfr. Socialtjänstlag 2001:453).
En ökad betoning på att försöka se ur barns perspektiv utmanar många invanda föreställningar, inte minst i socialt arbete (jfr. Andersson 2000). Man kan t.ex. fundera över begreppet "placeringu. De norska forskarna Agnes Andenæs och Kåre Skollerud (2003) framhåller: "Det de voksne snakker om som en plassering, er for barnet en flytting" (s. 24). Begreppet "flyttning i offentlig regi« signalerar att barnet är i centrum. Det är tänkvärt, eftersom det då blir tydligt att inte bara flyttning till familjehem eller institution utan också flyttning hem eller till eget boende är en flyttning $i$ offentlig regi, en flyttning som socialtjänsten gått med på, hjälpt till med eller arbetat för.

I forskning om stabilitet/instabilitet i placeringar utanför hemmet är det inte särskilt vanligt att fråga efter barns synpunkter eller hur nöjda/missnöjda de är med sin placering. Det finns emellertid en del tecken på att mått på stabilitet/instabilitet inte samvarierar med mått på tillfredsställelse eller "satisfaction". Hög grad av tillfredsställelse trots brist på stabilitet är inte ovanligt (Baldry \& Kemmis 1998). Sinclair (2005) och Sinclair et al. $(2005,2006)$ fann att även om de som forskare bekymrade sig för graden av instabilitet, kunde de konstatera att de flesta barnen i deras studier var nöjda med sin placering och ville stanna i fosterfamiljen, samtidigt som de ville behålla kontakt med sin biologiska familj eller delar av den (jfr. Gilligan 2000). Det var också tydligt i en mindre svensk studie om tioåringar i pågående familjehemsvård (Andersson 1998, 2001a) att barnen var nöjda med sitt familjehem och ville stanna eller behålla kontakten med fosterfamiljen, om eller när de flyttade hem. Barns nöjdhet 
är inget vanligt resultatmått, även om det finns en del internationella exempel på att barns tillfredsställelse, "satisfaction", ses som ett viktigt mått på kvalitet i vården (Heptinstall et al. 2001, Wilson \& Conroy 1999). Det framgår också att barns syn på sin familjehemsplacering är mer positiv än synen på institutionsplacering samt att deras syn på vården utanför hemmet hör ihop med vad de varit med om tidigare och hur de ser på sin biologiska familj.

I det projekt, som den här artikeln fortsättningsvis handlar om, togs barns erfarenheter tillvara medan de var barn (se t.ex. Andersson 1984, 1988, 1995, 1999, 2001b, Andersson \& Frick 1999). Deras tillbakablick på sina barndomserfarenheter torde kunna ge ytterligare kunskap om vad som kan vara viktigt för barn och vad man som vuxen bör vara uppmärksam på, lyssna efter och fråga om.

\section{Metod}

Undersökningsgruppen består av alla de 26 barn, som placerades på Stadens enda barnhem under en tvåårsperiod i början av 1980-talet och var 0-4 år gamla vid tiden för placeringen och stannade på barnhemmet mer än fyra veckor. ${ }^{1}$ Skäl till placeringen

1 Minnesgoda läsare minns att ursprungsundersökningen inkluderade 29 barn, som stannade minst tre veckor på barnhemmet. Det hade teoretiska grunder. Senare uppföljningar omfattar de 26 barn som stannade minst fyra veckor. Det har administrativa grunder, t.ex. uteslöts därmed barn som blivit omedelbart omhändertagna (per definition högst fyra veckor) utan fortsatt vård. var olämplig hemmiljö och brister i föräldraförmågan. Bakom det fanns väl kända riskindikatorer, som fattigdom, föräldrar/ ensamstående mamma med låg utbildning, utan arbete och beroende av försörjningsstöd/socialbidrag (jfr. Social rapport 2006). Därtill kom för några föräldrar psykisk sjukdom och/eller utvecklingsstörning men i de flesta fall missbruk. Föräldrars/mammors närvaro på barnhemmet uppmuntrades och det fanns en betoning på familjeinriktat arbete. Genom observationer, intervjuer, frågeformulär, sociala akter och journaler inhämtades information om barnen och deras familjer samt följdes barnens anknytnings- och anpassningsprocess under tiden på barnhemmet. Hälften av barnen flyttade från barnhemmet till endera föräldern och hälften flyttade till familjehem. När uppföljningar gjordes tre och nio månader efter barnhemsvistelsen var syftet framför allt att följa upp barnens anknytnings- och anpassningsprocess $\mathrm{i}$ hem och familjehem (Andersson 1984) och fortsatta uppföljningar var inte planerade. Det rikhaltiga och noggrant insamlade materialet från barnens tidiga barndom lade emellertid en fast grund för fortsatta uppföljningar 5, 10, 15, 20 och 25 år efter barnhemsvistelsen. ${ }^{2}$ I den här artikeln är det huvudsakligen intervjuer med barnen från de tre senaste uppföljningsomgångarna som används. I den femte uppföljningsstudien var de 15-20 år gamla, i den sjätte var de 20-25 år gamla och i den sjunde och sista var de 25-30 år gamla.

Alla intervjuer och övrig materialinsamling i den primära studien samt i de tre

2 Stiftelsen Allmänna Barnhuset har finansierat dessa uppföljningsstudier. 
första uppföljningsstudierna genomfördes av författaren medan intervjuerna i de fyra följande uppföljningsstudierna genomfördes av en medarbetare. Förutom intervjuer med olika berörda parter har ett antal standardiserade frågeformulär och skalor använts, men de används inte som underlag för den här artikeln (se t.ex. Andersson 2005). Sociala akter har gåtts igenom fram till det att barnen var 18 år och där finns all information om placeringar. I de tre senaste uppföljningsstudierna har enbart barnen och inte föräldrar och fosterföräldrar intervjuats. Intervjuerna innehöll frågor om social situation, relationer och välbefinnande såväl vid tiden för intervjun som de senaste fem åren samt tillbakablickar på barndomen och socialtjänstens insatser. Intervjuerna har bandats och skrivits ut ordagrant. Inför den här artikeln har jag läst igenom dem igen och särskilt tagit fasta på vad som sagts om placeringar. Det var min ambition att göra ett utsnitt av det som handlade om samhällsvård, men det gick inte att bortse från att synen på placering utanför hemmet hör ihop med erfarenheter av boende hemma eller synen på föräldrar, vilket därför skymtar i texten.

När begreppet placering används syftar det på placeringar enligt Socialtjänstlagen (SoL) eller Lagen med särskilda bestämmelser om Vård av Unga (LVU). I vad mån placeringar var med eller utan samtycke har inte redovisats, eftersom det inte har så stor betydelse i sammanhanget. Den ursprungliga placeringen på barnhemmet startade för de flesta med tvång men kunde omvandlas till placering med förälders samtycke eller omvänt. Omfattningen av tvångsvård var stort men kunde växla under barndo- men. Med begreppet samhällsvård menas vård utanför hemmet, på institution eller $\mathrm{i}$ familjehem, ett begrepp som i vissa publikationer ersatts med begreppet "social dygnsvård" eller bara „dygnsvård".

Mot bakgrund av noggranna kontroller från sociala akter, tidigare intervjuinformation från olika berörda parter samt senare intervjuinformation från barnen själva, skulle jag vilja påstå att det är en ovanligt heltäckande bild av en grupp barns hela placeringshistoria 0-18 år som presenteras. Eftersom barnens, de nu vuxnas, syn på placeringar och flyttningar är beroende av om erfarenheterna av placering inskränker sig till några månader på barnhem i tidig barndom eller omfattar större delen av barndomen i familjehem eller varvas med boende hos endera föräldern, var det i det här sammanhanget lämpligt att dela upp dem i fyra undergrupper (se Tabell 1-4).

För placeringshistoria finns inget bortfall, den är känd för alla barnen. Vad gäller barnens perspektiv på sina erfarenheter strider deras utsagor från de olika uppföljningsomgångarna vanligen inte mot varandra, men om så skulle vara fallet framgår det av texten. Bortfallet är litet och alla de 26 barnen har gjort sin röst hörd i vuxen ålder. I de intervjuer, som den här artikeln särskilt bygger på, var det ett bortfall av två i den femte och sjätte uppföljningsomgången och ett bortfall av fyra i den sjunde, men det var inte samma barn som tackade nej i de olika uppföljningsomgångarna. Därför finns alla barns röster med.

Det är en förhållandevis liten undersökningsgrupp, men urvalet är väl specificerat och kan representera barn som har en stor ansamling av riskfaktorer i sin familjebak- 
grund, har tidiga separationserfarenheter och tidiga erfarenheter av samhällsvård. Eftersom det är mitt syfte att visa på att det inom en sådan grupp finns individuell variation i placeringserfarenheter och i hur de ser på dessa erfarenheter, har jag bedömt det som angeläget att få med något citat från alla barnen, inte bara lyfta fram särskilt åskådliga exempel. Det är också för mig ett etiskt förhållningssätt att ge alla någon röst, eftersom de alla har medverkat vid upprepade tillfällen utifrån att deras erfarenheter har tillmätts betydelse. Citat är valda utifrån att de ska ge en underbyggd bild av deras perspektiv, en bild som jag tror de skulle finna "talande» eller representativ för deras syn i den händelse de skulle läsa texten (jfr. etiska överväganden, Andersson 2004.)

\section{Resultat}

Undersökningsgruppen delas upp i fyra undergrupper utifrån barndomens (0-18 år) placeringshistoria: Grupp 1) Sex barn flyttade hem till sina föräldrar eller endera föräldern efter den tidiga barnhemsvistelsen och omfattades inte av någon ytterligare samhällsvård. Grupp 2) Sju barn flyttade från barnhemmet till familjehem och stannande i samhällsvård under resten av barndomen. Grupp 3) Sju barn flyttade hem efter barnhemsvistelsen men återplacerades förr eller senare i samhällsvård. Grupp 4) Sex barn flyttade från barnhemmet till familjehem men återvände förr eller senare hem. I det följande behandlas dessa fyra grupper var för sig. Placeringar eller flyttningar mellan omsorgspersoner presenteras närmare i Tabell 1-4 från den tidpunkt då barnen blev en del av undersökningsgruppen, men i text framgår att något barn hade tidigare placeringserfarenheter. Även om barnens placeringshistoria slutar vid 18 år framgår i tabellerna om de bodde kvar längre (18+). I något fall har det varit relevant att ange flyttning till mormor, trots att det inte klart framgått av social akt att det varit en formell familjehemsplacering. Förkortningar som används i tabellerna är $\mathrm{BH}=$ barnhemmet, $\mathrm{FH}=$ fosterhem, $\mathrm{U}=$ ungdomsinstitution, $\mathrm{SB}=\mathrm{sammanbrott}$ eller oplanerat avbrott i placeringen, eget boende före 18 år benämns "själv«.

\section{Grupp 1. Ingen ytterligare samhällsvård efter tidig barnhemsvistelse}

De sex barnen i den här gruppen har inte återkommit i samhällsvård efter den tidiga barnhemsvistelsen. Som framgår av Tabell 1 flyttade alla utom ett barn hem till sin pappa. Det betyder att det fanns en pappa som bedömdes vara kapabel att ta hand om barnen, vilket skiljer dem från barnen i de andra grupperna, liksom att den utlösande orsaken till barnhemsplaceringen i de flesta fall inte var förälders missbruksproblem utan andra problem.

Göran och Fridolf gav uttryck för att de inte alltid haft det bra hemma. "Jag har ju aldrig gillat att bo hemma"; "Jag var ju aldrig där hemma, jag var jämt hos kompisar"; "Jag har alltid klarat mig själv«. Det betyder inte att de hade önskat att socialtjänsten skulle ha ingripit: "Jag hade ju inte velat bo någon annanstans ändå, man 
blir ju förstörd om man bor i familjehem!" Båda såg till att flytta hemifrån tidigt och valde en gymnasieskola som möjliggjorde flyttning. "Jag visste inte ens vad det var för utbildning". Det har funnits motgångar att klara av: "Jag tror det hade hjälpt med en tryggare familj."Båda minns det som att de flyttade mycket när de var små, "hit och dit». Under ett antal år bodde deras pappa tillsammans med en kvinna, som blev som en mamma för dem. Det är henne och inte sin pappa, som de i vuxen ålder har nära kontakt med.

Även Rosa och Sven är syskon. Deras barndom var påverkad av mammans psykiska sjukdom både före och efter föräldrarnas skilsmässa. "Mycket strul, mycket konflikter, så då blev det att jag drog mig över till min kompis familj", minns Rosa, "men man kan inte klandra... för man kan inte hjälpa att man blir sjuk.» Pappa fick hand om barnen men på grund av syskonkonflikter fick Sven flytta till mamma: "Men jag ville ju helst bo hela tiden hos min pappa. En "hoppig» barndom, minns Sven, "men på den tiden, när man växte upp, såg jag det inte som att det var något fel, det var det kanske, men det kan man inte gräva ner sig i«. Båda "älskarı den kvinna som pappa gifte om sig med, "jättesnäll och underbar».

David hade tidigare ett gott förhållande till sin mamma men uttryckte senare stark besvikelse: "Det var en bra tid när morsan bara levde med oss... innan hon beblandade sig med de där idioterna." Det är två olika män han tänker på. "Det blev en vändpunkt, för man förstod att man inte var önskad, det syns inte men det känns." Han ser det som "en taskig barndom" och "jag har så mycket hat och vrede inom mig". Den sista intervjun avstod han ifrån.

Gusten talar om "en stökig uppväxt» och säger om barndomen: »Ja, det var en väldigt otrygg period för mig, alltså min pappa flyttade ju väldigt mycket med mig, jag hann liksom aldrig skaffa kompisar och känna mig trygg och jag hoppade frän skola till skola, frain plats till plats hela tiden... Det var inte bara att han flyttade, han bytte fruar, kvinnor alltså... I tioårsåldern fick han flytta hem till mamma, "längtade alltid efter att komma hem till mamma, för jag trivdes ju aldrig hos min pappau. Det var kanske inte så att han fick stryk av sin pappa

\section{Tabell I.}

Barn som flyttade från barnhemmet till förälder utan ytterligare samhällsvård.

\begin{tabular}{|c|c|c|c|c|}
\hline Namn & $\begin{array}{c}\text { Till BH } \\
\text { ålder } \\
\text { mån. }\end{array}$ & $\begin{array}{c}\text { Från BH } \\
\text { efter } \\
\text { mån. }\end{array}$ & Till.. & $\begin{array}{l}\text { Bodde sedan } \\
\text {...ålder år upp till } 18\end{array}$ \\
\hline Göran & 3 & 6 & far & fart 16/17, sen själv \\
\hline Fridolf & 3 & 6 & far & fart $16 / 17$, sen själv \\
\hline Rosa & 12 & 3 & faromor & 10 år skilsmässa, far 10-18+ \\
\hline David & 28 & 3 & mor & mort $18+$ \\
\hline Gusten & 36 & 14 & far & far $4-10$, mor $10-18+$ \\
\hline Sven & 40 & 3 & faro mor & 13 år skilsmässa, far sen mort | 8+ \\
\hline
\end{tabular}


särskilt ofta, "men jag gick alltid omkring och var rädd för detw.

Ovanstående exempel visar att det inte går att säga att »återgång till hemmet utan återplaceringu är ett entydigt gott utfall ur berörda barns och ungas perspektiv. Möjligen kan socialtjänstens brist på insyn kopplas till att barnens hemförhållanden inte $\mathrm{i}$ första hand har präglats av missbruk utan av andra problem (jfr. Andersson 1991). Man kan fundera över varför det var fler pojkar än flickor i den här gruppen. Möjligen är det vanligare i social barnavård att fäder får hand om söner än döttrar?

\section{Grupp 2. Fortsatt samhällsvärd efter barnhemsvistelsen}

De sju barnen i den här gruppen flyttade alla från barnhemmet till familjehem och stannade i samhällsvård under resten av barndomen. För alla barnen var det ett s.k. främmande eller "traditionellt" familjehem, som de inte kände sedan tidigare. Alla kom att bo i ett och samma familjehem i 13 år eller mer, vilket är att betrakta som en uppväxt i familjehem. I ett fall övertog fosterföräldrarna vårdnaden och i tre fall var alternativet särskilt förordnad förmyndare, vilket inte helt sammanfaller med vilka två barn som blev adopterade av sina fosterföräldrar som vuxna.

Alla utom det yngsta barnet, som kom från barnklinik till barnhemmet, hade bott hemma före den barnhemsvistelse, som utgör startpunkten för den longitudinella studien. Några hade emellertid tidigare placeringserfarenheter: En pojke (Calle) hade varit i ett tidigare familjehem (närstående), en placering som avbröts oplanerat och följdes av omplacering till barnhemmet. En flicka (Karin) hade varit på barnhemmet under en kortare period en gång tidigare. Det kan också nämnas att det barn som hade undersökningsgruppens längsta inskrivningstid på barnhemmet (Anna)

\section{Tabell 2.}

Barn med fortsatt samhällsvård under barndomen.

\begin{tabular}{|c|c|c|c|c|}
\hline Namn & $\begin{array}{c}\text { Till } \\
\text { BH } \\
\text { ålder } \\
\text { mån. }\end{array}$ & $\begin{array}{l}\text { Från } \\
\text { BH } \\
\text { efter } \\
\text { mån }\end{array}$ & Till.. & $\begin{array}{l}\text { Bodde sedan } \\
\text {...ålder år upp till I } 8\end{array}$ \\
\hline Dag & 2 & 2 & $\mathrm{FH}$ & i samma FHt I8+ \\
\hline Anna & 10 & 22 & $\mathrm{FH}$ & i samma FHt I8+ \\
\hline Erik & 20 & 4 & $\mathrm{FH}$ & i samma FHt I8+ \\
\hline Mårten & 31 & I | & $\mathrm{FH}$ & i samma FHt I7,SB, själv fr 17 \\
\hline Calle & 31 & 2 & $\mathrm{FH}$ & i samma FHI t I5;SB, FH2 I6- I7,SB, UI, U2 \\
\hline Karin & 32 & 8 & $\mathrm{FH}$ & i samma FHt I8+ \\
\hline Eskil & 35 & 7 & $\mathrm{FH}$ & $\begin{array}{l}\text { i samma FH t I } 8 \text { (med två avbrott i behand- } \\
\text { lingshem) }\end{array}$ \\
\hline
\end{tabular}


under tiden hade två kortare inskolningsförsök i ett familjehem och en tid av shemgång på prov« innan hon kom till det familjehem, där hon sedan stannade.

Tre av barnen, Dag, Karin och Eskil, var de mest genuint förankrade i sina respektive fosterfamiljer. De uttryckte i varje uppföljningsstudie att de trivdes bra med sin fosterfamilj. Dag hade som 16-åring inte mycket att säga om placeringen, som han inte tänkte på som en placering. Det var hans familj, han hade det bra, hans mamma och pappa ställde upp för honom på alla sätt. Som 26-åring var han fortfarande nöjd: "Idealet måste vara som jag, att bli placerad som så liten att jag egentligen inte begriper det." Som vuxen hade han blivit adopterad av sina fosterföräldrar, vilket han inte tyckte gjorde någon skillnad, "mer juridiska grejer«. Karin sade i 18-årsåldern: "Jag trivs jättebra, det har jag alltid gjort... mina föräldrar (fosterföräldrarna) ställer upp för mig när jag behöver det och jag trivs jättebra med mina syskon." Fem år senare tänker hon likadant: "De har liksom alltid funnits där för mig och jag har alltid kunnat lita på dem." Ytterligare fem år senare: "Jag hade inte kunnat få det bättre... vi träffas flera gånger $i$ vecka." Det har känts bra hela tiden, menar hon, och det blev ingen större skillnad sedan hon blev adopterad i vuxen ålder. Eskil upprepade som 18-åring att han fortfarande trivdes bra med sina fosterföräldrar och "de har hjälpt mig när jag är $i$ knipaw. Fem år senare är han fri från missbruk och kriminalitet och fosterföräldrarna är fortfarande hans stora trygghet i livet: »Jag kunde inte ha kommit bättre, de har ju hällit ut med mig trots allt." Han har alltid kunnat lita på dem »och gör det fortfa- rande». Det var också gemensamt för dessa tre barn att de hade en försonlig inställning till sin familjebakgrund och till att deras mamma inte kunnat ta hand om dem.

Två barn, Anna och Erik, hade under barndomen sett sin fosterfamilj som sin familj, fosterföräldrarna var deras mamma och pappa. De såg fortfarande som vuxna positivt på sin placering, men det fanns bitoner. Båda använde ordet "hat» i förhållande till sina biologiska föräldrar. Återkommande var Annas svåra tankar om biologiska föräldrar, som övergivit henne och inte hörde av sig. Som 17-åring sade hon: "Det var ju bra att jag fick komma hit och bo här... om jag bott hos min biologiska mamma hade jag kanske varit nerknarkad och död nu.«När hon som vuxen såg tillbaka på sin barndom, sade hon: "Det enda jag tycker är sorgligt är att jag har varit så rädd och otrygg när jag var liten... rädd att jag skulle behöva flytta ... rädd att ingen skulle vilja ha mig." Erik hade det bra i sitt familjehem och var älskad av sina fosterföräldrar, det hade framgått i tidigare intervjuer. När han intervjuades som 24-åring tyckte han fortfarande att barndomen hade varit bra, men han hade inte längre kontakt med sina fosterföräldrar: "Det är ingenting som har hänt, det är bara att personkemin aldrig har klaffat riktigt... jäkligt svårt att förklara.. men vi har ju inte det där bandet liksom." Han har känt sig älskad av sina fosterföräldrar, men inte riktigt kunnat besvara deras kärlek, det är så han ser det. Sina biologiska föräldrar har han alltid tagit avstånd från: "När jag var yngre ville jag ju aldrig prata om dem för jag hatade dem så mycket."

Mårten och Calle var med om eller iscensatte sammanbrott i placeringar som 
varat under större delen av barndomen. För Mårtens del kom det inte helt överraskande, redan när han var yngre hade det funnits frågetecken om det var ett lämpligt familjehem för honom. På sin 17-årsdag hade han fått nog, "orkade inte meru. När han några år senare såg tillbaka på barndomen, sade han: "Den har varit svår, jag har inte tyckt om den... jag har förträngt det mesta." Men han hade fått hjälp av sin familjehemssekreterare att ordna eget boende, han hade redan berättat "allt « för henne, så hon förstod. "Jag mår bra sen jag flyttade, för då låg mitt självförtroende på botten." $\mathrm{Om}$ fosterföräldrarna sade han: "Jag vill inte se dem mer." Hans biologiska mamma hade funnits med i bilden, men vid 28 års ålder sade han: "Jag klarar inte av att träffa henne längre." Calles historia ser annorlunda ut, eftersom han hade det bra i sitt familjehem: "Man tog ju henne (fostermamman) nästan som sin biologiska morsa." Som 25-åring konstaterade han: "Det var en bra tid $i$ mitt liv, när jag bodde hos dem!" I tonåren hade det dock uppstått en konflikt, "gick ner på mitt rum och slog sönder grejer, sen gick jag". Han gick till en närstående till fosterfamiljen, som åtog sig att bli nytt familjehem, men "så strulade det till sig där. "De första fosterföräldrarna är döda och ingenting går att reparera, ensam och ledsen på institution gråter han och säger: "Jag pallar inte prata om allt gammalt. En sporadisk kontakt med sin biologiska mor har upphört, "klarar inte av att träffa henne».

För barnen i den här gruppen kom det att bli långtidsplacering eller uppväxt i familjehem, även om det i två fall slutade med sammanbrott. För de barn i gruppen, som fått "en familj för livet» i sin fosterfamilj har inte bara placeringens stabilitet varit avgörande. Ömsesidigt goda relationer är en viktigare förutsättning. Detta tycks höra ihop med eller påverkas av om barnen lyckats skaffa sig en försonlig inställning till sin familjebakgrund, något som vissa fosterföräldrar tycks klara bättre än andra att hjälpa dem med.

\section{Grupp 3. Barn som återvände hem men senare återkom $i$ samhällsvård}

De sju barnen i den här gruppen flyttade alla från barnhemmet hem till den förälder, som de tidigare hade bott hos. För barnen i den här gruppen fanns från socialtjänstens och barnhemmets sida en förhoppning om att barnen skulle kunna bo hemma med en rad stödinsatser. Några av barnen var kvar en tid som "dagbarn" på barnhemmet och/ eller hade uppföljande stödinsatser från familjens kontaktpersoner på barnhemmet. Några återvände kortare tid till barnhemmet vid akuta händelser i hemmet. Några hade stödfamilj/kontaktfamilj eller "sommarfamilj» och i några fall samarbetade socialtjänsten med farmor eller mormor, som kunde ta hand om barnen i kortare perioder av bekymmer, t.ex. återfall i missbruk eller bostadslöshet. Det dröjde en tid innan de återplacerades och flyttades till ett familjehem.

Det kan nämnas att två av barnen (Hanna, Frasse) hade varit på barnhemmet en gång tidigare, innan de blev en del av undersökningsgruppen, samt hade bott en kortare tid hos mormor respektive en närstående. 
När Berit inte längre kunde bo hos sin mamma på grund av hennes psykiska sjukdom hade hennes pappa blivit fri från sitt missbruk och kunde ta hand om henne. Farmor fanns i närheten och efter pappans återfall i missbruk blev hon formellt Berits fostermamma. "Farmor var jättebra, jag är så glad att hon fanns, annars vet jag inte vad som hänt.» Men det blev »kaos» och Berit fick allvarliga psykiska problem. Hon kunde inte bo kvar hos farmor, som inte kunde hindra pappans missbruksrelaterade våld, "jag var livrädd för honom». Efter några tillfälliga lösningar fick hon ett nytt familjehem, som hon inte var helt nöjd med. Som 15-åring ansåg hon: "Det fungerar... men jag tycker $i$ stort sett inte dom ska ha barn, för dom har inte tid med det». Två år senare hade hon flyttat därifrån, "de skilde sig så jag kunde inte bo kvar... och jag gillade inte henne och hon gillade inte mig."Som vuxen hade hon ingen kontakt med sitt andra familjehem men väl med sitt första, farmor.

Pelle fick flytta hem till sin pappa både efter barnhemsplaceringen och efter sin första familjehemsplacering, även om det inte var hållbart. Han var nöjd med att flytta tillbaka till sitt första familjehem, men efter en konflikt i tonåren "flippade det» och fostermamman sade i upprördhet: "Om det inte passar kan du packa!" Han packade och gick, även om han fram till dess tyckt att det var "skitbra» där. Han gick till en kompis vars familj blev Pelles andra familjehem. Återkommande i Pelles berättelser var att han »hatade« sin mamma

Tabell 3.

Barn som flyttade från barnhemmet hem men återkom $i$ samhällsvård.

\begin{tabular}{|c|c|c|c|c|}
\hline Namn & $\begin{array}{l}\text { Till } \\
\text { BH } \\
\text { ålder } \\
\text { mån. }\end{array}$ & $\begin{array}{c}\text { Från } \\
\text { BH } \\
\text { efter } \\
\text { mån }\end{array}$ & Till.. & $\begin{array}{l}\text { Bodde sedan } \\
\text {...ălder år upp till I } 8\end{array}$ \\
\hline Berit & 3 & 4 & mor & $\begin{array}{l}\text { mort 4, far 4- I0 (tidvis informellt farmor), FHI } \\
\text { (släkt) I0/I2- I5, SB, FH2 I5- I7,SB, sen själv }\end{array}$ \\
\hline Pelle & 23 & 9 & far & $\begin{array}{l}\text { efter ett halvår åter } \mathrm{BH}, \mathrm{FHI} 4 \text { 4- I0, far I0-I2, } \\
\text { samma FHI 12-16,SB,FH2 I6- I8+ }\end{array}$ \\
\hline Bodil & 24 & | | & mor & $\begin{array}{l}\text { mor (tidvis informellt mormor) t 9, FH 9-16, } \\
\text { SB, sen själv }\end{array}$ \\
\hline Cecilia & 36 & 5 & mor & $\begin{array}{l}\text { mor (tidvis åter BH) t 7, FHI 7- I I, mor I I- I2, } \\
\text { FH2 (släkt) I3- I5, SB, samma FH। | 6- I } 8\end{array}$ \\
\hline Anders & 37 & | | & mor & $\begin{array}{l}\text { mor (tidvis informellt mormor) t } 10, \mathrm{FH} 10 \\
-18+\end{array}$ \\
\hline Hanna & 39 & I & mor & $\begin{array}{l}\text { mor (tidvis informellt mormor) t I3, FHI } \\
\text { I 3- I4, sen gatan/mor/FH2/ UI m.fl. (många } \\
\text { växlingar och SB, FH, U, svårt följa, akten borta }\end{array}$ \\
\hline Frasse & 42 & 15 & mor & $\begin{array}{l}\text { mort 8, åter BH 8-9, FHI (släkt) 9- I2, SB, FH2 } \\
\text { (släkt) I2-I8+ }\end{array}$ \\
\hline
\end{tabular}


men "älskade» sin pappa, som dog när Pelle var 19 "och allt gick utföru. När han intervjuades i 23-årsåldern hade han bra kontakt med sitt andra fosterhem men inte med sitt första, men fem år senare var det tvärtom. Han hade återknutit kontakten med sitt första familjehem: "Sms och mail nästan varje vecka... och jag vet att jag alltid kan köra hem till /f.d. fostermamman/ och få mat om det skulle köra ihop sig fullständigt."

Bodil och Anders var syskon. Bodil hade farit mest illa hemma men Anders talade om " misärr. En tid var mamma och barn placerade i ett familjehem tillsammans. Olika stödinsatser räckte inte till och i nio-tioårsåldern placerades barnen i familjehem. Bodil trivdes inte där. Hon hade rymt några gånger och från 16-årsåldern bott själv med olika stödinsatser från socialtjänsten. När hon som 18-åring berättade om familjehemmet, sade hon: "Det gick inte en dag utan att vi var ovänner, jag hade bättre självförtroende innan jag flyttade dit." Som vuxen ser hon sin barndom som "stulen barndom... det känns verkligen så, att man inte fätt ha någon barndomu. Kontakten med mamman "sårar och skadar migu och om familjehemmet säger hon: "Jävla otur alltså att hamna där!ณ När hon blev gravid var det ändå sin f.d. fostermamma hon ringde och "hon hjälpte migjättemycket när /barnet/föddesw. Anders hade en betydligt mer positiv bild av samma familjehem. Fosterfamiljen "betyder mycket för mig... man har känt sig trygg... och känt sig uppskattadu. Som 25-åring såg han dem fortfarande som sin familj, "och de har uppfattat mig som sin son«.

Cecilia minns barndomen hemma som "in och ut på barnhem«. Det var "rätt att ta oss från mammau, menade hon. Efter en tid i familjehem flyttade hon hem, planerat, med mormor i närheten och en "sommarfamilj». Hon var placerad hos mormor en tid, men när hon inte kunde eller orkade bo där längre ringde hon själv till sitt första familjehem och bad att få komma tillbaka. Som 23-åring menade hon: "Det är ju min fosterfamilj som är min familj... dom fanns där hela tiden, även när jag flyttade hem emellan, jag fick ju flytta tillbaks ibland dà också, när det var problem." Som 28-åring säger hon: "Det är dem jag älskar som mina föräldrar och det är dem jag skulle önska att jag hade som föräldrar, då hade jag varit som alla andra."Sin mamma har hon som vuxen gles kontakt med men har en försonlig inställning till henne: "Jag har inget emot henne, hon kunde inte hantera situationen bara."

Frasse tänkte tillbaka på sin barndom som att han "blivit flyttad hit och dit och har inte kunnat rota mig någonstans." Han bevittnade mycket våld när han bodde hemma och "man blev väldigt räddk. Han var emellertid glad att ha blivit placerad inom släkten. Det oplanerade avbrottet/ sammanbrottet i placeringen hos morbror blev inte svårt, eftersom han fick flytta till sin mormor. Som vuxen menade han att han "alltid sett mormor som min familj... mormor var räddningen för migu. Han har "alltid" haft kontakt med sin mamma men tycker att det var "absolut rätt» att han blev familjehemsplacerad.

Hanna var det barn i gruppen som fick bo kvar hemma längst och först i efterhand berättade hon om styvfaderns misshandel och sexuella övergrepp. Ingen utomstående visste eller lyssnade på henne, menade hon. En tid var hon familjehemsplacerad hos sin 
"sommarfamilj" men kom hem igen. Vid 14 års ålder lämnade hon hemmet för gott för gatan, prostitution, missbruk, kriminalitet, självmordsförsök. "Folk har inte tagit mig på allvar." I tonåren blev det familjehems- och institutionsvård med rymningar och avbrutna placeringar. Även som vuxen har hon haft olika avbrutna placeringar på behandlingshem. Mormor var död, den enda som stått henne nära. Ett familjehem hade hållit viss kontakt på senare tid, "det är precis som de försöker... de är skumma». Hon kunde inte lita på att de ville henne väl.

Alla barnen i den här gruppen hade bott hemma efter barnhemsvistelsen och när de placerades i familjehem hade de påtagliga och smärtsamma minnen med sig hemifrån, inte sällan kopplade till föräldrars missbruk, familjevåld eller att de varit vittne till våld. Som unga vuxna betonade de att det var rätt att de fick flytta till familjehem. De flesta hade varit med om sammanbrott eller oplanerade avbrott i sin familjehemsplacering, men det uteslöt inte att de hade trivts i sitt familjehem eller ett av dem. De flesta hade i vuxen ålder fortsatt kontakt med f.d. fosterföräldrar.

\section{Grupp 4. Barn som omplacerades till familjehem men senare återvände hem}

De sex barnen i den här gruppen flyttade alla från barnhemmet till familjehem men har också det gemensamt att de fick flytta hem till mamma efter två-tre år i familjehem. Hemflyttningen var planerad för alla och var en följd av att deras mamma hade gått in för att ordna upp sin sociala situation och komma till rätta med sitt missbruk samt bedömdes klara av att ta hand om barnen igen. För ett barn (Ola) avslutades visserligen familjehemsplaceringen oplanerat och han återkom till barnhemmet, men det intensifierade familjearbetet ledde till planerad hemgång. Redan före skolåldern var således barnen i den här gruppen återförenade med sina mammor. De stannade hemma i minst två år och i ett kortare tidsperspektiv kan man således tala om ett gott resultat av samhällsvård. Det var emellertid inte slutet på deras placeringshistoria. Det var bara två av barnen i den här gruppen (Nilla, Viola) som inte återkom i samhällsvård.

De tre flickorna $\mathrm{i}$ gruppen hade en del gemensamt. Både flickorna och deras mammor kände redan de blivande fosterföräldrarna och hade en god relation till dem, när barnen placerades i familjehem. En fostermamma var barnets kontaktperson på barnhemmet, en var dagmamma och en var barnets mormor. Det var genomgående positiva berättelser om fosterföräldrarna.

När Viola flyttade hem tappade hon så småningom kontakten med sin fostermamma, men som vuxen menade hon att fostermamman "alltid funnits $i$ tanken". Hon hade wen lycklig barndom och det är tack vare mamma... hon har verkligen lyckats skydda mig." Det betydde också att hon skyddade Viola från vetskap om vad som hänt i familjen under tidig barndom och inte heller ville att Viola skulle medverka i uppföljningsstudier. Det var först när Viola flyttat hemifrån som hennes mamma återföll i missbruk och "då gick det bara neråt», tills hon dog av en överdos. I Violas tillbaka- 
blick som vuxen uttrycker hon tacksamhet mot sin mamma: "Med facit $i$ hand så har hon skött det strålande, definitivt." Nilla återkom inte heller i samhällsvård under sin barndom men säger som vuxen: »Jag tycker jag haft en svår uppväxt. Värst där hemma var "de jävla idiotkarlarna hon /mammal har träffat ... man blir ju så besviken på henne». När hon i tonåren inte fick någon hjälp från socialtjänsten för att komma hemifrån flyttade hon först tillbaka till mormor och sedan till eget boende. Ingrid bodde hemma några år i mellanbarndomen men hade fortsatt kontakt med sin fosterfamilj, som var kontaktfamilj i mellantiden, innan Ingrid återplacerades där. Som hon minns det var hon alltid där på helger och lov och kunde ringa dit, när det var svårt hemma. Det var i återkommande intervjuer hennes fosterfamilj, som var hennes familj, "dom har ju alltid stått mig närmast». Som 27-åring tyckte hon fortfarande: „De är fantastiska människor båda två... och / min son/ tycker det är så roligt att vara där. Ingrid hade tidigare känt sig försonad med sin mammas tillkortakommanden men menade att besvikelsen över föräldrarnas missbruk hade tilltagit, sedan hon själv fått barn.

De tre pojkarna i den här gruppen har också en del gemensamt. Redan innan de kom med i forskningsprojektet hade de varit omhändertagna för samhällsvård, om än under en kortare period. Från den barnhemsvistelse, som utgjorde startpunkten för forskningsprojektet, flyttade de till familjehem, men deras mammor kämpade

\section{Tabell 4.}

Barn som flyttade från barnhemmet till familjehem men senare återvände hem.

\begin{tabular}{|c|c|c|c|c|}
\hline Namn & $\begin{array}{l}\text { Till } \\
\text { BH } \\
\text { ålder } \\
\text { mån. }\end{array}$ & $\begin{array}{l}\text { Från } \\
\text { BH } \\
\text { efter } \\
\text { mån }\end{array}$ & Till.. & $\begin{array}{l}\text { Bodde sedan } \\
\text {...ålder år upp till I } 8\end{array}$ \\
\hline Ingrid & 14 & 14 & $\mathrm{FH}$ & FHI 2-5, mor 6-12, samma FHI I3-18+ \\
\hline Ola & 15 & 10 & $\mathrm{FH}$ & $\begin{array}{l}\mathrm{FHI} \text { (släkt) 2-3, SB, åter BH sen mor, FH2 } \\
\text { 7- I I,mor I I- I3, UI, SB, U2, mort I 4, FH2, SB, } \\
\text { FH3, (SB?), U2, från I } 5 \text { svårt följa alla växlingar }\end{array}$ \\
\hline Torsten & 21 & 10 & $\mathrm{FH}$ & $\begin{array}{l}\text { FHI 2-4, mor 4-6, BH, samma FHI 7-I0, SB, } \\
\text { FH2 I0-II, mor II- I2, UI, mor, U2 vid I4, U3 } \\
\text { vid U6, U4, U5 vid I7, mor emellan, svårt följa } \\
\text { alla växlingar }\end{array}$ \\
\hline Nilla & 33 & 3 & $\mathrm{FH}$ & $\begin{array}{l}\text { FH (släkt) 3-6, mor, (tidvis informellt mormor), } \\
\text { från I } 7 \text { själv. }\end{array}$ \\
\hline Viola & 37 & 2 & $\mathrm{FH}$ & FH 3-5, mor 6-18 \\
\hline Uffe & 43 & 10 & $\mathrm{FH}$ & $\begin{array}{l}\text { FHI 4-6, mor 6-8, åter } \mathrm{BH}, \mathrm{FH} 2 \text { 9- I 3, mor, far } \\
\text { vid I4, UI vid I5, far, åter UI, far vid I 6, U2 } \\
\text { (SB?), U3, FH3 vid I7, U4, åter FH3, åter U4, } \\
\text { åter FH3, svårt följa alla växlingar }\end{array}$ \\
\hline
\end{tabular}


hårt för att få hem barnen och genomgick olika missbruksbehandlingar. Barnen var med om mer än en hemgång, mer än en återplacering, mer än ett sammanbrott/ oplanerat avbrott i placeringar, mer än en omplacering. De blev tidigt brottsaktiva och i tonåren bodde de på olika ungdomsinstitutioner och var kända för ungdomskriminalitet, missbruk, rymningar. Alla tre har också erfarenhet av fängelsevistelser som unga vuxna.

Ola har som vuxen inga goda minnen av fosterhem, utom av en fosterfar som han bodde hos ett par år i tonåren. Om barndomen säger han: "Det var bara besvikelser och svek hela mitt liv ... mina föräldrar de har supit och knarkat... sen när man kom till fosterhem så har de antingen slagit på en eller hatat en och inte velat ha mig kvar." Ett återkommande minne är den första ungdomsinstitutionen i 13-14-årsåldern: "Det är sådana ställen man lär sig all skit på, så har det inte gått snett innan så gör det det där. När han i vuxen ålder ser tillbaka på sitt liv, med sitt hat, sitt missbruk, sin kriminalitet, sitt våld, sammanfattar han: "För jävligt rent ut sagt, riktigt åt helvete." Torsten och Uffe var syskon och har varit i mer än ett familjehem, tillsammans och var för sig. Familjehemmen de bott i hade de inte några dåliga minnen av men heller inte någon fortsatt kontakt med. "Ingen av dem som betydde något för mig", sade Torsten som 18-åring. Några år senare tänkte han att han kanske hade klarat sig bättre i livet, om han fått stanna kvar i sitt första, "det var därjag trivdes». Uffe hade nog stannat i sitt andra familjehem, om de inte flyttat, för då ville han inte flytta med. Båda pojkarna hade mer att säga om sina erfarenheter av institutionsvård och kunde jämföra olika ungdomsinstitutioner med varandra. Torstens värsta erfarenhet var första gången han blev "satt" på institution, "jag var yngst bland alla kriminellau. Efter det "så slutade jag bry migu. När han som 27-åring ser tillbaka på sitt liv, så är sammanfattningen: "Ren katastrof måste jag säga." Uffe hade positiva minnen från en ungdomsinstitution, där både reglerna och personalen var bra, men i princip var det inte stor skillnad mellan ungdomsinstitutioner och fängelse, menade han, "det är bara lite andra regler". Det blev flera institutionsplaceringar men periodvis bodde Uffe i ett familjehem, hos en närstående, som han har behållit kontakt med som vuxen. De kom väl överens.

Som vuxna tänkte också barnen i den här gruppen en hel del på hur barndomen varit. De flesta hade levt i perioder med sin mammas missbruk och bevittnat våld, fått klara sig själva och känt sig otrygga. De menade att det utan tvekan var rätt att placera dem i familjehem. Det var inte det som var problemet. Flickorna hade positiva minnen från sina familjehem. Pojkarnas familjehemserfarenheter hade trängts tillbaka av senare erfarenheter av institutioner av olika slag och andra svåra händelser.

\section{Sammanfattning och diskussion}

De här barnens placeringserfarenheter började tidigare än för de flesta. Som en jämförelse kan nämnas att av alla de barn (0-18/20 år), som påbörjade heldygnsinsatser år 2006 (Socialstyrelsen 2007) var det bara en femtedel (dvs. 1435 barn) som var 
i förskoleåldern (0-6 år). Det förekommer även idag att barn i förskoleåldern placeras en tid på barnhem/HVB för utredning, familjebehandling eller förberedelse för familjehemsplacering, även om det blivit vanligare att förälder erbjuds bo tillsammans med barnet. Av de 26 barnen i den här aktuella undersökningsgruppen, som alla hade barnhemserfarenheter före fyra års ålder, kom tre fjärdedelar att också få familjehemserfarenheter. En fjärdedel av dem kom också att få erfarenhet av ungdomsinstitutioner.

Det finns inga jämförbara undersökningar som följer barns placeringshistoria under hela barndomen (0-18 år), men helhetsintrycket är i enlighet med andra studier, nämligen hög grad av instabilitet på grund av flyttningar inom barnavårdssystemet. Erfarenhet av sammanbrott/oplanerade avbrott hade 10 av 26 barn eller 38, 5 procent, vilket är tämligen jämförbart med andra undersökningar med andra urvalsprinciper, där 30-37 procent är en andel som nämns (se Egelund 2006, Vinnerljung et al. 2001). Flyttningar inom barnavårdssystemet beror vanligen på sammanbrott/ oplanerade avbrott i pågående placering, vilket kan vara förödande för barn. I jämförelse med internationell forskning ska man kanske ändå vara försiktig med vad som ska betecknas som många placeringar. Så många som 20-30 flyttningar inom barnavårdssystemet, "placement moves", eller mer än tio placeringar inom en treårsperiod (McCarthy 2004) var det inte tal om. Av undersökningsgruppens 20 barn med erfarenhet av familjehemsvård hade tolv bara bott $\mathrm{i}$ ett familjehem och fyra hade bott i två. Det var „bara» för fyra (som kan omräknas till 20 procent) som det var svårt att hålla reda på placeringar, sammanbrott, omplaceringar och återplaceringar i familjehems- och institutionsvård. Det finns också anledning att komma ihåg att stabilitet inte alltid är av godo, om man betänker att det finns barn som inte trivs i sitt familjehem och kan uppleva sammanbrott som en lättnad. Det är på sin plats att betona vikten av att ta barns röst på allvar, även inom social barnavård. Inget system kan förbättras utan feed-back från barnen (Wilson \& Conroy 1999).

Det finns studier som försökt komma fram till vilka faktorer som ökar eller minskar risken för sammanbrott, men resultaten är inte entydiga. När bara tonårsplaceringar studerats (Vinnerljung et al. 2001) har det framgått att släktingplaceringar är mer förskonade från sammanbrott än s.k. vanliga familjehem. Så var det inte i den här aktuella studien, eftersom fyra av fem släktingplaceringar avbröts oplanerat, dock inte nödvändigtvis $i$ tonåren utan långt tidigare. I en metaanalys av 26 studier (Oosterman et al. 2006) kunde författarna inte identifiera några enstaka risk- eller skyddsfaktorer med starkt förklaringsvärde för ökad eller minskad risk för sammanbrott ("disruptionsı) i familjehemsplaceringar. Inte heller släktingplacering hade förklaringsvärde.

En ännu mer bidragande orsak till instabilitet i barndomen än flyttningar inom barnavårdssystemet visade sig vara flyttningar mellan barnavårdssystemet och hemmet. Det har framgått av andra studier att det inte är ovanligt med återplaceringar (jfr. Vinnerljung et al. 2004a, 2004b). Räknat på hela barndomen hade 12 av 26 barn i den här aktuella undersökningsgruppen eller 46 
procent upplevt återplaceringar efter hemgång. Det är detta som Sinclair et al. (2006) framhåller som en paradox, nämligen att instabilitet $i$ vårdsystemet representerar ett försök att åstadkomma stabilitet i familjen. Återplacering representerar då vanligen misslyckande med att ge barnen stabilitet i sin egen familj, vilket i sin tur kan bero på att barnen flyttar hem för tidigt och/ eller att stödet i hemmiljön är bristfälligt. Fler mellanpositioner, "midway positions", mer av delad omsorg, wshared relationships", som Sinclair (2005 s. 103) föreslår, skulle vara barnen till gagn. När jag lyssnar på barnen i min undersökningsgrupp blir det tydligt att de i alltför stor utsträckning blivit utlämnade åt sig själva efter återförening med en förälder, som inte kommit till rätta med sina problem eller återfallit i missbruk långt innan det nådde myndigheterna att barnen for illa av det. Missbruksbehandling för föräldrar vore till gagn för barn långt in i vuxen ålder, eftersom det kan bli dubbelt smärtsamt för dem att se de egna barnen lida av mor- och farföräldrars missbruk. Det är nog så, som Lina Ponnert (2007) fann i sin avhandling, att socialsekreterare är mer försiktiga i bedömningar och åtgärder när det gäller föräldrars oacceptabla beteende än när det gäller tonåringars oacceptabla beteende.

Det är tydligt även i mina studier att bristen på stabilitet är mer bekymmersamt än frågan om barns nöjdhet eller tillfredsställelse ("satisfaction") med familjehem. De flesta var nöjda med sitt familjehem ett av dem. Förhållandevis många (12 av 20) hade behållit kontinuerlig kontakt med f.d. fosterföräldrar i vuxen ålder. Det går inte att särskilja synen på familjehemsplacering från synen på föräldrarna/mamman. Det var min ursprungliga intention att begränsa den här artikeln till placeringar och barns synpunkter eller tillbakablick på placeringar. Det visade sig emellertid vara nära kopplat till synen på föräldrarnas brister och tillkortakommanden samt i vad mån de som vuxna försonats med eller accepterat deras brister och tillkortakommanden. June Thoburn (1994) talar om fosterbarn som har frid, "peace", med sig själva och sitt förflutna. Sinclair et al. (2005) talar om vikten av att hjälpa barnet komma fram till ett "modus vivendi" med sina föräldrar, så att deras sinnen inte slits mellan längtan och avståndstagande (min översättning, se s. 259). Det framstår även i mina studier som ett viktigt observandum att det är både viktigt och möjligt att försonas med svåra barndomserfarenheter, annars ger de svåra avtryck långt in i vuxenlivet (jfr. Andersson 2008). En del fosterföräldrar och föräldrar lyckades hjälpa barnen med detta arbete, men det verkar inte som det ingår i socialtjänstens ansvar. I försoningsarbetet hör samhällsvård och familjerelationer nära ihop och jag är böjd att citera Gilligan (2000 s. 43): „Du kan ta barnet ur sin familj, men du kan inte ta familjen ur barnet" (min översättning). Ett relevant tilläggsmått på utfall av samhällsvård skulle kunna vara i vad mån barnen fått hjälp att försonas med sina barndomserfarenheter eller fått hjälp att förhålla sig till dem eller hantera dem på ett uthärdligt sätt. 


\section{Referenser}

Andenæs, Agnes (1991) „Fra undersøkelseobjekt til medforsker? Livsformsintervju med 4-5-åringer." Nordisk Psykologi vol. 43 (4), s. 274-292.

Andenæs, Agnes \& Skollerud, Kåre H. (2003) „Flytting i offentlig regiw. I E. Backe-Hansen (red.) Barn utenfor hjemmet. Flytting i barnevernets regi. Oslo: Gyldendal.

Andersson, Gunvor (1984) Små barn på barnhem. Lund: Lunds Universitet, Psykologiska institutionen (akademisk avhandling).

Andersson, Gunvor (1988) En uppföljning av barn som skilts frän sina föräldrar. Lund: Lunds universitet, Meddelande från Socialhögskolan, nr 1 .

Andersson, Gunvor (1991) Socialt arbete med smà barn. Lund: Studentlitteratur.

Andersson, Gunvor (1995) Barn i samhällsvård. Lund: Studentlitteratur.

Andersson, Gunvor (1998) „Föräldrakontakt och familjetillhörighet ur fosterbarns perspektiv." Socialvetenskaplig tidskrift vol. $5 \mathrm{nr}$ 1, s. 3-23.

Andersson, Gunvor (1999) „Children in residential and foster care - a Swedish example." International Journal of Social Welfare vol. $8 \mathrm{nr} \mathrm{4,}$ October, pp. 253-266.

Andersson, Gunvor (2000) „Barnen i socialt arbeteen maktlös grupp?»I A. Meeuwisse, S. Sunesson \& H. Swärd (red.) Socialt arbete. En grundbok. Stockholm: Natur och Kultur (första upplagan).

Andersson, Gunvor (2001 a) »Barns vardagsliv i familjehem." I M. Bäck-Wiklund \& T. Lundström (red.) Barns vardag $i$ det senmoderna samhället. Stockholm: Natur och Kultur.

Andersson, Gunvor (2001 b) „Jag försöker gå framåt men vinden drar mig bakåt'. En barndom utan kontinuitet." I G. Andersson, K. Aronsson, S. Hessle, A. Hollander \& T. Lundström Haverier i social barnavård? Fem fallstudier. Stockholm: Gothia/CUS.

Andersson, Gunvor (2004) "Vårt ansvar för de svaga." I H. Jönson (red.) En kompanjonbok till Forskningsetik och perspektivval. Femton texter till Rosmari Eliasson-Lappalainen. Lund: Studentlitteratur.
Andersson, Gunvor (2005) „Family relations, adjustment and well-being in a longitudinal study of children in care." Child and Family Social Work vol. 10, pp. 43-56.

Andersson, Gunvor (2008) „Foster children - a longitudinal study of placements and family relationships." International Journal of Social Welfare DOI: 10.1111/j.14682397.2008.00570.x.

Andersson, Gunvor \& Frick, Agneta (1999) „Barndom i samhällsvård - vad säger ungdomarna?» I I. Claezon, B. Hjälm \& M. Söderfeldt (red.) Brobygget. Kunskapsutveckling och participatorisk forskning i socialt arbete. Malmö: Malmö Högskola, Hälsa och samhälle.

Andersson, Gunvor \& Rasmusson, Bodil (2006) „Fosterbarns perspektiv på socialtjänstens företrädare." Socialmedicinsk tidskrift årg. $83 \mathrm{nr} 1$, s. 5- 15.

Baldry, Sally \& Kemmis, John (1998) »Research Note. What is it Like to be Looked After by a Local Authority?" British Journal of Social Work vol. 28, pp. 129-136.

Cederborg, Ann-Christin \& Karlsson, Yvonne (2001) "Omhändertagande med barnets perspektiv." Socialvetenskaplig tidskrift $\mathrm{nr} 3$, s. 63-179.

Claezon, Ingrid (2004) Tvångsomhändertaganden. Ur tonåringars, anhörigas och socialsekreterares perspektiv. Stockholm: Mareld.

Corsaro, William A. (2005) The Sociology of Childhood. Thousand Oaks: Pine Forge Press.

Egelund, Tine (2006) Sammanbrud $i$ anbringelser. En forskningsmoessig belysning. København: Socialforskningsinsittuttet, 06:01.

Egelund, Tine \& Hestbæk, Anne-Dorthe (2003) Anbringelse af børn og unge uden for hjemmet. En forskningsoversigt. København: Socialforskningsinstituttet.

Egelund Nielsen, Henrik (2001) »Så kommer du til et bedre sted..... København: Forlaget Børn \& Unge, Pedagogisk Centrum.

Gilligan, Robbie (2000) »The Importance of Listening to the Child in Foster Care.» I G. Kelly \& 
R. Gilligan (eds.) Issues in Foster Care. Policy. Practice and Research. London: Jessica Kingsley.

Halldén, Gunilla (2003) „Barnperspektiv som ideologiskt eller metodologiskt begrepp." Pedagogisk Forskning i Sverigeårg. $8 \mathrm{nr}$ 1-2, s. 12-23.

Heptinstall Ellen, Bhopal Kalwant \& Brannen Julia (2001) "Adjusting to a foster family." Adoption \& Fostering vol. $25 \mathrm{nr}$ 4, pp. 6-16.

James Allison, Jenks Cris \& Prout Alan (1998) Theorizing Childhood. Cambridge: Polity Press.

Kampmann, Jan (1998) Børn som informanter. Arbejdsnotat udarbejdet for Børnerådet. København: Socialministeriet, Børnerådet.

McCarthy, Gerard (2004) „The developmental histories of children who experience high levels of placement instability in the care system." Adoption \& Fostering vol. $28 \mathrm{nr}$ 4, pp. 60-65.

Oosterman M, Schuengel C, Slot N.W., Bullens R \& Doreleijers T (2007) "Disruptions in foster care: A review and meta analysis." Children and Youth Services Review vol. 29, pp. 53-76.

Ponnert, Lina (2007) Mellan klient och rättssystem. Tvångsvård av barn och unga ur socialsekreterares perspektiv. Lund: Lunds universitet, Socialhögskolan, Dissertations in Social Work 29.

Rasmusson, Bodil (1994) Barnperspektiv. Reflektioner kring ett mångtydigt och föränderligt begrepp. Stockholm: Barnombudsmannen.

Rasmusson, Bodil (2006) Barnperspektiv i den sociala barnavården. Forsknings- och utvecklingsarbete inom ramen för projekt Kunskapsbaserad socialtjänst. Lund: Lunds universitet, Meddelande från Socialhögskolan, nr 2.

Rasmusson Bodil, Hyvönen Ulf \& Mellberg Lina (2004) Utvärderingsmöten i BBIC. En studie om barns delaktighet och medbestämmande. Stockholm: Socialstyrelsen.

Sallnäs Marie, Vinnerljung Bo \& Kyhle Westermark Pia (2004) "Breakdown of teenage placements in Swedish foster and residential care." Child and Family Social work vol. 9 (2), pp. 141-152.

Sinclair, Ian (2005) Fostering Now. Messages from Research. London, Jessica Kingsley.
Sinclair Ian, Baker Claire, Wilson Kate \& Gibbs Ian (2005) Foster Children. Where They Go and How They Get On. London: Jessica Kingsley.

Sinclair Ian, Wilson Kate \& Gibbs Ian (2006) Foster Placements. Why They Succeed and Why They Fail. London: Jessica Kingsley (second impression).

Seim, Sissel \& Slettebø, Tor (red.) (2007) Brukermedvirkning i barnevernet. Oslo: Universitetsforlaget.

Social rapport 2006. Stockholm: Socialstyrelsen.

Socialstyrelsen (2003) Brukarmedverkan i social tjänstens kunskapsutveckling. Stockholm: Socialstyrelsen.

Socialstyrelsen (2007) Barn och unga - insatser år 2006. Stockholm: Socialstyrelsen, Statistik Socialtjänst 2007:9.

Socialtjänstlag(SFS 2001:453).

Tiller, Per-Olav (1991) „'Barnperspektivet': Om å se og bli sett. Vårt perspektiv på barn - eller omvendt?" Barn. Nytt fra Forskning om Barn nr 1, s. 72-77.

Thoburn, June (1994) Child Placement: Principles and Practice. Aldershot: Arena (second edition).

Ward, Harriet. \& Jackson, Sonia (1991) „Research Note: Developing Outcome Measures in Child Care." British Journal of Social Work vol. 21, pp. 393-399.

Wilson, Leslie \& Conroy, James (1999) "Satisfaction of children in out-of-home care." Child Welfare vol. $78 \mathrm{nr}$ 1, pp. 53-70.

Vinnerljung Bo, Sallnäs Marie \& Kyhle Westermark Pia (2001) Sammanbrott vid tonårsplaceringar - om ungdomar $i$ fosterhem och på institution. Stockholm: Socialstyrelsen, CUS.

Vinnerljung Bo, Öman Maria \& Gunnarson Thomas (2004a). "Återplacering av barn i dygnsvård (I): - hur vanligt är det?" Socialvetenskaplig tidskrift vol.11 $\mathrm{nr}$ 1, s. 54-75.

Vinnerljung Bo, Hjern Anders \& Öman Maria (2004b) »Återplacering av barn i dygnsvård (II) - vad ökar eller minskar risken?" Socialvetenskaplig tidskrift vol. $11 \mathrm{nr} 2$, s. 150-167. 


\section{Summary}

\section{Childhood placements and young persons'retrospect}

The primary study initiating this longitudinal project was an in-depth study of all the 26 children who were placed in the one remaining children's home in a city in Sweden at some time during a two-year period at the beginning of the 1980s and who were $0-4$ years old at the time of the placement and stayed there for at least four weeks. Follow-up studies were carried out 3 and 9 months after the children left the children's home and 5, 10, 15, 20 and 25 years later. This article makes a survey of the children's placement history up to age 18 and conveys their retrospective views as young persons, using interview data from the latest three follow-up studies. As regards out-of-home care after leaving the children's home, the children can be divided into four groups: (1) about a quarter of the children had no further out-of-home placements; (2) about a quarter were in out-of-home care during the rest of their childhood; (3) about a quarter returned home after the children's home but were later replaced; (4) about a quarter left the children's home for foster homes but later returned home. This means that 20 of the 26 children in the research group had experiences of foster care and half of them also of breakdown in care, not always seen as bad. Most of the former foster children were satisfied with their foster family or one of them. The young persons' retrospective views on care did not always run together with their experiences of stability/ instability in care. Their relationship with foster parents and their views on parents' imperfections and shortcomings also played a part, and to what extent they had become reconciled with their past, or had come to a "modus vivendi« (Sinclair et al. 2005) with their parents. 